\title{
Bilingual Education in Colleges and Universities of China
}

\author{
Chuanlian Song \\ School of Economics \& Management \\ Changchun University of Science \& Technology, Changchun 130022, China \\ E-mail:chuanliansong@163.com
}

\begin{abstract}
At present, there are many problems in the bilingual teaching of colleges and universities. Because of these problems, the bilingual education looks so difficult that it doesn't achieve wanted goals. Sometimes the colleges and universities have to give up the bilingual teaching halfway. This paper argues that the key manner to improve effectiveness of bilingual teaching is how to do the bilingual education. This paper discusses the current problems and relevant measures for improving the effect of bilingual education.
\end{abstract}

Keywords: Bilingual education, Problems, Countermeasures

\section{Introduction}

Along with the coming of economic globalization and global informatization, together with the speed- up opening up and the frequent international contracts, the bilingual education that takes Chinese and English as the media languages is springing up. However, because the bilingual education in colleges and universities of China faces kinds of problems, the bilingual education does not achieve an ideal effect under many conditions. This paper means to probe into the problems in bilingual education in colleges and universities of China, and advanced countermeasures, with the hope of helping colleges and universities achieve the goal of bilingual education.

\section{The definition of bilingual education and meanings for adopting bilingual education in colleges and universities}

\subsection{The definition of bilingual education}

As for bilingual education, not a definition is widely accepted. This paper agrees that "bilingual education", as a teaching method, takes mother language and foreign language (mainly English due to its wide popularization) as the teaching media, and help students master the specialty knowledge. This teaching method can extend students' knowledge scope, expand horizons, and make them master the specialty knowledge better, for the sake of adapting to the economic globalization.

\subsection{Meanings for bilingual education in colleges and universities of China}

(1) Providing a foreign language learning environment

It is well known linguistic environment is extremely important for the acquirement and development of language. We can master our mother language without effort rightly because we are surrounded by a strong mother language environment. We acquire the mother language by involvement but not learning. Learning a foreign language also needs a better linguistic environment. The bilingual education can create a favorable linguistic environment for students learning foreign language. But the main objective of bilingual education is not to improve students' foreign language level. Its most important meaning is to strengthen the subject construction and train complex talents for economic globalization.

(2) Strengthing subject construction

If apply the bilingual education well, it can strengthen subject construction. Reasons are as follow:

Firstly, bilingual education selects the teaching materials directly introducing from foreign county, with some adjustments, which can absorb the merits of foreign textbooks and the latest teaching contents.

Secondly, it can expand the teaching thoughts. In bilingual education, teachers use two textbooks respectively in Chinese and English. Then, teachers can obtain the spirits of teaching ideas in two countries, helping the students to deepen their understandings to the specialty knowledge.

Finally, it can update teachers' knowledge structure. Teachers can get more deepening understandings to the specialty knowledge, driving the subject construction.

(3) Trainng complex talents for economic globalization

At present, because of the division of specialties, many people merely master their specialty knowledge, knowing 
nothing about other subjects. However, along with China's economic development, more and more industries need complex talents who master both specialties and foreign language. Bilingual education is an important way training complex talents.

\section{Problems in current bilingual education of colleges and universities in China}

3.1 Colleges and universities in China can not recognize the relationship of bilingual education and foreign teaching In many people's opinion, bilingual education is the extension of foreign teaching. Its existence is for the sake of teaching foreign language. They agree that the basic foreign language teaching may be canceled along with the further development of bilingual education. Or, they think that bilingual education is equal to foreign language teaching.

\subsection{Teachers can not recognize the relationship between bilingual education and specialty teaching}

These people think that bilingual education is to introduce foreign terms in specialty teaching. They only focus on specialty teaching in mother language but not interpreting latest foreign development of certain subject.

\subsection{Colleges and universities in China are lack of qualified original English teaching materials}

Statistical data show that most Chinese students can not accept the original English teaching materials due to their high prices. Some Chinese publishing houses have already photocopied the original English teaching materials, which can greatly decrease the costs. Wide teachers and students can accept the price of photocopied textbook. However, only Lixin Accounting Publishing House, China Economy \& Trade Press, Tsinghua University Press, and China Machine Press publish the photocopied foreign teaching materials. And they merely focus on several fixed textbooks. More subjects do not possess photocopied foreign teaching materials. In a sense, these facts serve as barriers for starting bilingual education.

(4) Weak teaching power in colleges and universities of China being an important actor

In China, bilingual education needs teachers who are good at both English and specialties. However, bilingual education is still a new thing in China. Many teachers do not pass specialized bilingual training. They are just experimenting on bilingual education. It influences the quality of bilingual education to a great degree.

(5) Being lack of scientific bilingual education program and rushing into bilingual education without considering the difference of subjects

In some colleges and universities, teachers who speak English well can open bilingual classes. As a result, some subjects are not right for bilingual education. Unfortunately, it is hard to achieve a better effect.

(6) Different level of students' English resulting teachers can not master the teaching process properly.

After the expansion of colleges and universities, most teachers feel that students' English is at a lower level. Many students can not pass the CET 4. As for bilingual education, no mater how hard the teacher instructs the class, students with poor English can not learn. In addition, due to the problems in English teaching, most students are not good at listening. Teachers have to slow the teaching speed in bilateral communication with students.

\section{The countermeasures for improving the quality of bilingual education in colleges and universities}

\subsection{Coordinate the relationship of bilingual education, foreign language teaching, and subject teaching}

We should know that bilingual education is a teaching method taking two languages as teaching media. Its aim is not only to teach specialty English or introduce foreign specialty knowledge. Its ultimate aim is to improve students' specialty level, expand their horizon, and extend their knowledge. Therefore, if the teacher merely teach specialty English, it is not proper. If merely introduce foreign specialty knowledge, it is not in accordance with Chinese conditions and betrays the aim of bilingual education in China. Nothing but the mother language can help students understand the specialty knowledge well. Therefore, in bilingual education, we should control the degree: insuring that students can master specialty knowledge, and learn more knowledge.

\subsection{Introduce qualified original teaching materials}

We should focus on several issues as we introduce the teaching materials. Firstly, the teaching materials should respect domestic specialties' characteristics and needs, including basic knowledge and latest development. Secondly, the teaching materials should catch up with the development of international relevant specialties, being in accordance with the requirements for social needs. Thirdly, the teaching materials should take the conditions of bilingual education in China into consideration. Fourthly, the teaching materials should be coordinated with other courses. The introduced teaching materials must be qualified. It is better to pass the experts' confirmation, which can effectively avoid waste of sources. Increase the kinds and quantities of teaching materials. 


\subsection{Emphasize on the train of teachers and the teaching power}

In America, teachers who are engaged in bilingual education should not only possess strong English ability and specialty knowledge, but also have the certificate issued by the ministry of education. In China, teachers who are engaged in bilingual education are far from this standard. Therefore, we should take the training of bilingual teachers as an urgent task, building a bilingual teacher team, in which teachers are good at both English and specialties. The best way is to absorb overseas returnees. However, the returnees can not satisfy the needs for bilingual teachers. We should dig out the potentials of present teachers. Firstly, colleges and universities can select excellent teachers to get further education in domestic or foreign first-class universities. Secondly, encourage English teachers to learn other specialty courses and specialty teachers learn foreign languages. By this way, teachers can combine their specialties and foreign languages well.

\subsection{Improve students' English level and equip bilingual courses with other measures}

Firstly, increase students' specialty terms. Secondly, improve students' listening ability. Thirdly, strengthen students' after-class reading. In detail, we can hand out some original foreign materials and take them as case studies. Organize students to answer questions in class. Finally, adopt an interactive teaching method. Make students participate in the class. Help students explain specialty meanings and ask specialty questions in English.

\subsection{Adopt a step-by-step way and open bilingual courses gradually}

For some specialties, courses may be difficult or easy. Colleges and universities can try bilingual education firstly from easy courses. Increase time for these courses and insure the teaching effect. Enhance students and teachers' confidence in bilingual education. Open bilingual courses from easy to hard and step by step.

Besides, in a macro aspect, we must offer relevant policy support in order to develop bilingual education well. For example, the state should organize experts to research on the courses right for bilingual education, compose relevant bilingual education program. Make the bilingual education be in accordance with China's present conditions and specialties. More examples: Build a special bilingual education evaluation system, and improve bilingual teachers' treatments.

\section{References}

Song, Chuanlian. (2003). Probe into the loss of virtual assets of colleges and universities of China. Journal of Changchun University of Science and Technology. No.2.

Song, Chuanlian. (2008). On problems affecting college teaching quality and relevant measures. China Educational Technique \& Equipment. No.7. 